\title{
The STUDENTSCALE: Measuring Students' Motivation, Interest, Learning Resources and Styles
}

\author{
Rui Moreira ${ }^{(凶)}$, Cláudia Seabra, José Luís Abrantes, and Belmiro Rego \\ Polytechnic Institute of Viseu, Viseu, Portugal \\ rjfmoreira@gmail.com, \{cseabra,jlabrantes\}@estv.ipv.pt, \\ brego@esev.ipv.pt
}

\begin{abstract}
It becomes important to consider the role of Information Technologies (IT) in society and at school, including its impact on the teaching-learning process transformation. The use of IT should be done in an integrated and inclusive way, it is critical to teach how to use, consume and interact with technology. This study intends to contribute to a more depth understanding of the IT impact in the teaching-learning process. Our main goal is to create a scale to measure the Subjects' Interest and Motivation, Motivation and Involvement with Learning Resources and Learning Styles. Those are important factors that impact on students' Learning Performance. Insights from an empirical study of 357middle education students indicate that this multi-dimensional scale incorporates the following constructs: a) Interest and Motivation, b) Motivation and Involvement with IT's Learning Resources, c) Motivation and Involvement with Teachers' Learning Resources, and d) Non Literary Learning Styles. Discussion centers on this scale implications for theory development and management decisions. Teachers' and schools' managers may better understand the learning resources and styles preferred by students, and thus to create more motivational learning programs. Directions for future research are also presented.
\end{abstract}

Keywords: Pedagogy $\cdot$ Student behavior $\cdot$ Learning resources $\cdot$ Learning styles

\section{Introduction}

Students are now more demanding and know what they want and what they like. Teachers must be alert and keep interaction to motivate the students daily. From a young age, they learn to live with the Information and Communication Technologies (IT). It is crucial to understand the IT role in nowadays society, including its impact on the teaching-learning process. IT can contribute to the teaching and learning current paradigm changing. The school must become an intercultural place where students abandon their passive position to be active agents in their own learning. Teachers should leave their isolated position of single agents to also turn themselves into the students' pupils and partners in the teaching process. This requires the use of IT in schools in an integrated and inclusive way, to teach how to use, consume and interact with technology in a critical way (Bridges, 1999). 
This study aims to understand what factors contribute to a better learning environment in the students' perspective. Also, how the education, learning and motivation for students change with the use of IT and multimedia resources in the classroom. Specifically this study main goal is to build a scale to measure the antecedents of student's Learning Performance: Students' Social Context - i) Student/Teacher; ii) Student/Student, and iii) School/Family; Personal Factors and Learning Styles - i) Motivation and Student's Interest, ii) Student's Behavior, and iii) Learning Styles; Learning Resources - i) the Use of Teacher's Resources, and ii) the Use of Technology.

\section{Literature Review}

The growing importance of IT in schools provokes several debates and discussions on its effectiveness in the student's learning rhythms, in the role of teachers and students, and even in the role of the school as institutions. Proponents of universalized use of IT in schools proclaim that this use allows developing new capabilities in students' learning, to extend their horizons in a diverse and global scale (McGrath, 1997-1998). On the opposite side, those who criticize IT use argue that it limits and constrains students learning, transforming them in passive receivers of information, making them socially isolated people (Abrahamson, 1998).

In this study, we adopt a cautious position on the perspective in which the use of IT itself may not be sufficient to explain and characterize the new students. Other factors may be behind the students' performance, and that will influence the way they perceive the school and therefore the use of IT, such as the student's social context, personal factors, learning styles, and learning resources.

\subsection{Students' Social Context}

The need to engage students and make them active and interested participants in the classroom has been recognized by many researchers (Hay, Hodgkinson, Peltier, \& Drago,2004; Lowman \& Mathie, 1993; Webster \& Hackley, 1997). In fact, that interaction has been identified as a key factor in the learning experience (Vygotsky, 1978). In the current pedagogical relationship there are components considered essential: the student, his personality, the family and social context, the teacher, his personality, the social environment, specifically the family and society as a whole (Mialaret, 1992).

The student's performance depends on many factors that are not limited to their cognitive and/or learning performance capabilities. The environment, the social and educational context in which the learning process takes place is also essential (Young, 2005). Most elements of the school community consider school as a more enjoyable and useful place when they believe that others appreciate and value them in their environment (Goodenow \& Grady, 1993). This is also a motivating factor for learning (Weiner, 1990). In sum, creating a productive learning environment requires a climate in which students feel good about themselves, about their peers and teachers and the social environment as a whole.

In line with the above, we considered the relationship of the student to the school environment in the following areas: i) student/ teacher; ii) student/student, iii) 
school/family, supported by research on cooperative learning and reciprocal teaching (eg. Johnson \& Johnson, 1991; Palincsar \& Brown, 1984;Slavin, 1990), the study of social interaction as a primary source of cognitive development (Rogoff, 1990; Vygotsky, 1978), in research on the effects of friendship, school adjustment (Berndt \& Keefe, 1992) and the study of the influence of social context variables in cognitive, motivational, and educational processes (Goodenow, 1992; Weiner 1990).

\subsection{Personal Factors and Learning Styles}

When a student is interested and motivated, his learning is more effective. Also, the teacher's role is facilitated (Abrantes, Seabra \& Lages, 2007; Young, Klemz \& Murphy 2003). Students reject learning environments that they don't like and, moreover, their perception of learning is worse in those environments (Hsu, 1999). In this context, student's intrinsic factors, the learning environment and styles are important issues to examine how students focus on the contents (Young et al., 2003; Hamer, 2000; Clarke III, Flaherty \& Mottner, 2001). The theory of learning styles points to individual preference-related factors, such as: environment, emotions, interactions and physical needs that have an impact on the learning process (Dunn \& Griggs, 1995). On the other hand, students with similar preferences in terms of learning styles have similar choices in what regards to subjects and courses; also they prefer teachers with teaching methods tailored to their learning styles (Kolb, 1988). Other researchers have shown that there is a correlation between learning styles with preferences for work (Lashinger \& Boss, 1984), educational involvement, motivation and learning (Honey

\& Mumford, 1992), and student performance (Brokaw \& Mertz, 2000).

In this context, it is important to analyze the learning environments that the student values and his perspective on what facilitates his learning process. We considered in personal factors and learning styles: i) motivation and student's interest, ii) student's behavior iii) and learning styles.

\subsection{Learning Resources}

Teachers have several techniques to prepare their lessons, however with the technological advances the decision is increasingly complex. In addition, many teachers carefully weigh the potential effect of new teaching techniques introduction in their students' evaluation (Clarke III et al., 2001).

Several educational resources and methods have been analyzed in the literature such as exercises in class, lectures, use of case studies (Davis, Misra \& Van Auken, 2000), combination of written and electronic channels (McNeilly \& Ranney, 1998), collection and projects research group, teamwork (Bridges, 1999), and the effect of classroom activities on student learning process (Hamer, 2000).Other studies suggest also that a student's favorable attitude concerning the teaching style leads to better outcomes, and that the relationship between the teaching methods and learning styles results in a more effective learning (Dunn et al., 1990).

The use of technological resources and IT in classrooms is common and recurring today. Potentially, students may withdraw several advantages of technologies use: first for their own skills development in using IT; also IT use offers new ways of me- 
diated learning helping students to receive information more effectively, giving them more autonomy and freedom, and increasing their performance (Aleven \& Koedinger, 2002; Hunt, Eagle \& Kitchen, 2004).

Regarding the use of teacher's resources there is great unanimity among researchers as to the need for replacement of passive methods for models of experiential and interactive learning (Davis et al., 2000; McNeilly \& Ranney, 1998; Hamer, 2000). However, the use of IT in teaching learning raised several questions about the best combination of educational resources. The perspective that the IT use in the classroom is beneficial and effective does not invalidate the importance of using other traditional teaching resources (Berry, 1993). Both teaching resources - with and without the IT use - are important to students. Both resources should not be exclusionary and can live side by side complementing themselves in the teaching/learning process (Hamer, 2000).

We considered the learning resources as including i) the use of teacher's resources and ii) the use of technology.

\section{$3 \quad$ Methodology}

This study was developed based on a survey to students in $7^{\text {th }}, 8^{\text {th }}$ and $9^{\text {th }}$ year of school in Portuguese schools. The questionnaire was developed based on previous scales (e.g. Abrantes et al., 2007; Hunt et al., 2004). An online questionnaire was proposed to the students between February and April of 2013. 255 questionnaires were validated from 257 questionnaires received.

Regarding the socio-demographic profile, the sample consists mainly of females $(53.5 \%)$. The most represented age groups is between 13 and 14 years $(30 \%$ and $29.7 \%$ respectively). Most students in the sample never failed $(69.7 \%), 21.3 \%$ failed once, twice $(7.3 \%)$, and only $8 \%$ failed three or four times. When asked about the daily study time beyond school hours, half of the students said that they spent about one to two hours daily, 34\% studied less than an hour per day. Regarding the household, most of the respondents' fathers where factory or agriculture workers $(51.3 \%)$ or commercial/administrative $(11.2 \%)$, the mothers were mainly housewives $(25.2 \%)$, factory or agriculture workers (24.9\%), and business administration employees $(19 \%)$.

\section{$4 \quad$ Results}

In this study we analyzed the factors that could impact on learning process and environment valued by students, including family involvement with the school, student interest, styles and learning resources. The responses' frequency analysis allowed us to draw some results:

- There is a great involvement of the parents with the school, as well as an active participation in school and extracurricular activities.

- Parents have an absolute knowledge of children's situation in school. 
- Students reported that their main motivations to school were linked with the satisfaction in improving their knowledge and personal skills, interest in learning interesting things, and self-actualization.

- However, the expectations to complete the studies are low for most students.

- Students recognize that there are different learning styles causing different stimuli for the knowledge acquisition.

- When comparing learning resources, students prefer the use of IT in relation to reading and listening contents.

- Students value the teacher's role, namely what he says, advises or encourages them to do.

- Most of the students stated that they like to work with IT, referring that they feel very comfortable in using those resources, demonstrating familiarity, proximity, and frequent use of IT.

- In what regards to learning resources, a large proportion of students reported reduced use of IT in schools, including email, chat, teacher's webpage, research in the online library, video and audio conferencing.

- The resources that students identified as the most used were textbooks, homework, tests/exams and assignments in class. Thus, it continues to dominate the use of non IT resources.

To address the main goal of this study - building a scale to measure the antecedents of student's learning performance -, the items were subjected to a confirmatory factor analysis (CFA), using full-information maximum likelihood (FIML) estimation procedures in LISREL 8.8 (Jöreskog\&Sörbom, 1996). In this model, each item is restricted to load on its pre-specified factor, with the three first-order factors allowed to correlate freely. After CFA purification, a list of 18 items was found. A full listing of the 18 final items after CFA purification and their scale reliabilities is shown in Table 1.

The chi-square for this model is significant $\left(\chi^{2}=249,95,129 \mathrm{df}, \mathrm{p}<.00\right)$. Since the chi-square statistic is sensitive to sample size, we also assessed additional fit indices: Normed Fit Index (NFI), Comparative Fit Index (CFI), the Incremental Fit Index (IFI), and the Tucker-Lewis Fit Index (TLI). The NFI, CFI, IFI and TLI of this model are $.97, .99, .99$, and .98 , respectively.

As can be seen in Table 1, convergent validity is evidenced by the large and significant standardized loadings of each item on its intended construct (average loading size is 0.786 and 16.90). Also all constructs presented desirable levels of composite reliability (Bagozzi, 1980). Discriminant validity among the constructs was stringently assessed using the Fornell and Larcker (1981) test; all possible pairs of constructs passed this test; more specifically, the average variance extracted was above the recommended level of 0.50 for all three constructs. Evidence of discriminant validity was also revealed by the fact that all the constructs' inter-correlations were significantly different from 1 and the shared variance between any two constructs (i.e. the square of their inter-correlations) was less than the average variance extracted for each construct.

Hence, none of the correlations in the final model was sufficiently high to jeopardize the constructs' discriminant validity (Anderson \&Gerbing, 1988). 
Table 1. The STUDENTSCALE- Constructs, scale items, reliabilities and T-Values

\begin{tabular}{|c|c|c|}
\hline Constructs, Measur ement Scales and Internal Reliability & Std.Coeficientes & T-values \\
\hline \multicolumn{3}{|l|}{ INTEREST AND MOTIVATION TO THE SUBJECT } \\
\hline \multicolumn{3}{|l|}{ (Scale 1=Totally Disagree / 5=Totally Agree) } \\
\hline \multicolumn{3}{|l|}{ IMSUBJECT - Interest and Motivation to the Subject ${ }^{1}\left(\alpha=, 93, p_{n}\{i \mathrm{n}=, 67, p=.93)\right.$} \\
\hline I am interested in learning History & 0.86 & 20.06 \\
\hline I am generally attentive during the History classes & 0.70 & 14.95 \\
\hline I am becoming more competent in this área since I have this subject & 0.78 & 1731 \\
\hline I am learning a lot in this subject & 0.87 & 20.61 \\
\hline I have positive feelings about this subject & 0.89 & 21.36 \\
\hline I am interested in the History contents & 0.88 & 20.78 \\
\hline Is really importante to me to be a good student in History. & 0.72 & 15.54 \\
\hline \multicolumn{3}{|l|}{${ }^{1}$ Adapted fram Hunt, Eagle \& Kitchen, 2004 and Abrantes, Seabra \& Lages, 2007} \\
\hline \multicolumn{3}{|l|}{$\begin{array}{l}\text { MOTIVATION AND INVOLVEMENT WITH ICT LEARNING RESOURCES } \\
\text { (Scale } 1=\text { Totally Disagree } / 5=\text { Totally Agree) }\end{array}$} \\
\hline \multicolumn{3}{|l|}{ ICTMI-Motivation and Invdvement with ICT Learning Resources ${ }^{2}\left(\alpha=, 90, p_{1, \alpha}=, 67, p=.91\right)$} \\
\hline Computers and te chnolog ical information help me to have a better learning experience. & 0.84 & 19.12 \\
\hline Computers and te chnolog ical information help me to learn. & 0.89 & 21.13 \\
\hline V10 The use of technological information enhances my motivation to learn. & 0.84 & 19.21 \\
\hline V11 Ilike to work with computers. & 0.80 & 1784 \\
\hline V12 I am con fident when I have to work with computers & 0.69 & 14.53 \\
\hline \multicolumn{3}{|l|}{${ }^{2}$ Adapted from Hunt, Eagle \& Kitchen, 2004} \\
\hline \multicolumn{3}{|l|}{$\begin{array}{l}\text { LEARNING RESOURCES MADE BY TEACHERS } \\
\text { (Scale } 1=\text { Totally Disagree } / 5=\text { Totally Agree) }\end{array}$} \\
\hline \multicolumn{3}{|l|}{ TEACHERLR - Learning Resources made by Teachers $\left(\alpha=81, \rho_{\mathrm{g}}(\mathrm{i})=52, \rho=81\right)$} \\
\hline School books & 0.72 & 1454 \\
\hline Homework & 0.76 & 15.43 \\
\hline Tests/exams & 0.75 & 15.26 \\
\hline V16 Exercises in class & 0.65 & 12.64 \\
\hline \multicolumn{3}{|l|}{3 Adapted fram de Hunt, Eagle \& Kitchen, 2004} \\
\hline \multicolumn{3}{|l|}{ NONLITERATY LEARNING STYLES } \\
\hline \multirow{2}{*}{\multicolumn{3}{|c|}{ 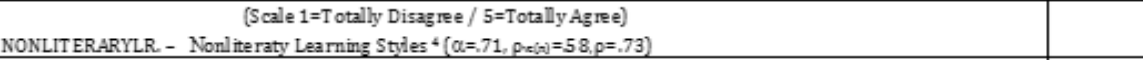 }} \\
\hline & & \\
\hline I understand better graphics than written contents. & 0.86 & 13.18 \\
\hline $\begin{array}{l}\text { V18 I recall better what I see or graphics than what I read or hear. } \\
\text { A Adapted from Hunt, Eagle \& Kitchen, } 2004\end{array}$ & 0.65 & 1082 \\
\hline Notas $\alpha=$ Internal reliability (Cronbach, 1951) & & \\
\hline $\begin{array}{l}\text { prán }=\text { (Fornell \& Larler, } 1981 \text { ) } \\
p=\text { Composit Rel iability (Bagozzi 1980) }\end{array}$ & & \\
\hline
\end{tabular}

\section{Conclusions, Implications and Limitations}

The main aim of this study was to understand the factors, in the students' perspective, that could contribute to a better learning environment. Specifically to measure and analyze the student's performance antecedents such as students' social context, namely the students' relationship with their peers and the family involvement with the school; students' personal factors and learning styles; and the learning resources used.

The main results show that families are involved with school and that is something that students value; also, in general, students are motivated with school since they understand that learning impacts their future. Also, students are aware of the different learning resources and have different learning styles, however besides their preference on IT, students give importance to the teacher's role, namely in what regards to trust, confidence in knowledge, and willingness to help. Thus, it appears that the empathy created between elements in the teaching-learning process is crucial to the educational success. 
It was also possible to build a scale to measure the Student's Motivation and Interest, Resources and Learning Styles- the STUDENTSCALE that consists in four dimensions:

- Interest and Motivation to the subject,

- Motivation and engagement with IT learning resources,

- Learning Resources made by Teachers.

- Nonliterary Learning Styles.

The framework developed in this study can be used to measure the students' interest and motivation, the teaching resources and learning styles valued and preferred by students. The existence of these four dimensions allows us to conclude that students consider the importance of i) Interest and Motivation for the subject, ii) Motivation and Engagement with IT Learning Resources, iii) Resources for Learning made by Teachers, and iv) Non-Literary Learning Styles as a whole for their learning process.

The present study can help education managers and responsible to have a middle education students' profile, also the resources that are used in our schools. So, we can realize who these students are, but also which is the actual learning environment of our schools.

The scale presented helps to know and analyze the motivation, interest, learning resources and styles valued and preferred by students. We were also able to measure the use of IT and multimedia in teaching, verifying the investment made by the governments and managers in the schools regarding hardware and software, knowing if they are used frequently by students and teachers. We can conclude that managers should invest on equipment, but also in teachers' training so they can use IT properly and diversify their strategies meeting the increasingly "technological" students.

Also, the STUDENTSCALE purpose is to contribute to a better understanding of the learning resources and styles used by teachers in classes. This framework helps teachers to select the best and more effective methodologies and learning resources to match the students' learning styles, motivating them and achieving a greater educational success.

From the research point of view it is also expected to make a relevant contribution to science in the IT' impact study, namely in the school and in the teaching/learning process. The work presented contributes thus to the development of literature in education in the various social sciences through the following implications: better understanding of the students' interests, measurement of learning styles and resources, development of scales and better understanding of learning styles, resources' impact in the learning process, and the impact of all those aspects on improving students' and teachers' skills, providing more performance and success of the learning process.

There are some limitations to be considered. The first limitation is that the final instrument (i.e. the questionnaire) may have created common method variance. This could be particularly threatening if the respondents were aware of the conceptual framework. However, they were not told the specific purpose of the study, and all of the construct items were separated and mixed so that no respondent would be able to detect which items were affecting which factors. Second, while the reported research investigates the learning performance antecedents for middle education students, the study can extend beyond this specific research set, specifically to other education levels. Hence, although the fit indices suggest a good fit of the model to the data, future research is encouraged to test our instrument across different education levels. To do so, we encourage researchers to add new items and factors applicable to the research setting. Continued refinement of the STUDENTSCALE proposed and supported in this study is certainly possible based on further qualitative research. 
Thirdly, the research context involved students in Portugal, which may limit the generalizability of the results to some degree. The STUDENTSCALE should also be applied in other countries. To establish its generalizability, multiple samples in other contexts are also suggested. Finally, further research is required when analyzing the antecedents and consequences of the STUDENTSCALE.

Acknowledgments. The Instituto Politécnico de Viseu, the Center for Studies in Education, Technologies and Health (CI\&DETS) and the Portuguese Foundation for Science and Technology (FCT).

\section{References}

Abrahamsom, C.: Issues in interactive communication in distance education. College Student Journal 32(1), 33-43 (1998)

Abrantes, J., Seabra, C., Lages, L.: Major determinants of students' perceived learning: Pedagogical affect, student interest and learning performance. Journal of Business Research 60(9), 960-964 (2007)

Aleven, V., Koedinger, K.: An effective metacognitive strategy: Learning by doing and explaining with a computer-based cognitive tutor. Cognitive Science 26, 147-179 (2002)

Anderson, J., Gerbing, D.: Structural equation modeling in practice: A review and recommended two-step approach. Psychological Bulletin 103(3), 411-423 (1988)

Bagozzi, R.: Causal models in marketing. John Wiley, New York (1980)

Berndt, T., Keefe, K.: Friends' influence on adolescents' perceptions of themselves at school. In: Meece, D.H. (ed.) Student Perceptions in the Classroom, pp. 51-73. LEA, Hillsdale (1992)

Berry, L.: Our roles as educator: Present and future. Journal of Marketing Education 15, 3-8 (1993)

Bridges, E.: Experiential learning and customer needs in the undergraduate marketing research course. Journal of Marketing Education 21(1), 51-59 (1999)

Brokaw, A.: The effects of students' behaviour and preferred learning style on performance. Journal of Business Research 1, 44-53 (2000)

Brokaw, A., Merz, T.E.: The effects of student behavior and preferred learning style performance. Journal of Business Education, 44-53 (2000)

Clarke III, I., Flaherty, T.B., Mottner, S.: Student perceptions of educational technology tools. Journal of Marketing Education 23(3), 169-177 (2001)

Davis, R., Auken, S.M.: Relating pedagogical preference of marketing seniors and alumni to attitude toward the major. Journal of Marketing Education 22(2), 147-154 (2000)

Davis, R., Misra, S., Van Auken, S.: Relating pedagogical preference of marketing seniors and alumni to attitude towards the major. Journal of Marketing Education 22, 147-154 (2000)

Dunn, R., Griggs, S.: Multiculturalism and learning style: Teaching and clousing adolescents. Praeger, Westport (1995)

Dunn, R., Giannitti, M., Murray, J., Rossi, I.: Grouping students for instruction: Effects of learning style on achievement and attitudes. Journal of Social Psychology 130, 485-494 (1990)

Fornell, C., Larcker, D.: Evaluating structural equation models with unobservable variables and measurement error. Journal of Marketing Research 18, 39-50 (1981)

Goodenow, C.: Strengthening the links between educational psychology and the study of social contexts. Educational Psychologist 27, 177-196 (1992)

Goodenow, C., Grady, K.E.: The relationship of school belonging and friends' values to academic motivation among urban adolescent students. Journal of Experimental Education 62(1), 60-71 (1993) 
Hamer, L.: The additive effects of semistructured classroom activities on student learning: An application of classroom-based experiential learning techniques. Journal of Marketing Education 22(1), 25-34 (2000)

Hay, A., Hodgkinson, M., Peltier, J., Drago, W.: Interaction and virtual learning. Strategic Change 13(4), 193-204 (2004)

Honey, P., Mumford, A.: The manual of learning styles. Maidenhead, Berkshire (1992)

Hsu, C.: Learning styles of hospitality students: Nature or nurture. Hospitality Management 18(3), 17-30 (1999)

Hunt, L., Eagle, L., Kitchen, P.: Balancing marketing education and information technology: Matching needs or needing a better match? Journal of Marketing Education 26(1), 75-88 (2004)

Johnson, D., Johnson, R.: Learning together and alone. Prentice-Hall, Englewood Cliffs (1991)

Jöreskog, K., Sorbom, D.: LISREL 8: User's reference guide. Scientific Software International, Chicago (1996)

Kolb, D.: Learning styles and disciplinary differences. California Mangement Review 18(3), 22-31 (1988)

Lashinger, H.K., Boss, M.W.: Learning styles and nursing students and career choices. Journal of Advanced Nursing 9, 375-380 (1984)

Leung, D.Y., Kember, D.: The relationship between approaches to learning and reflection upon practice. Educational Psychology 23(1), 61-71 (2003)

Lowman, J., Mathie, V.: What should graduate teaching assistants know about teaching? Teaching of Psychology 29(2), 84-88 (1993)

McGrath, C.: A new voice on interchange: Is it talking or writing? Implications for the teaching literature. Journal of Educational Techonology Systems 26, 291-297 (1997-1998)

McNeilly, K., Ranney, F.: Combining writing and electronic media in sales management courses. Journal of Marketing Education 20(fall), 226-235 (1998)

Mialaret, G.: Psicopedagogia. Dom Quixote, Lisboa (1992)

Palincsar, A., Brown, A.: Reciprocal teaching of comprehension-fostering and comprehensionmonioring activities. Cognition and Instruction 1, 117-175 (1984)

Peltier, J.W., Drago, W., Schibrowsky, J.A.: Virtual communities and the assessment of online marketing education. Journal of Marketing Education 25, 260-276 (2003)

Prelow, H.M., Loukas, A.: The role of resource, protective, and risk factors on academic achievement-related outcomes of economically disadvantaged Latino Youth. Journal of Community Psychology 31(5), 513-529 (2003)

Rogoff, B.: Apprenticeship in thinking: Cognitive development in social context. Oxford University Press, New York (1990)

Slavin, R.: Cooperative learning: Theory, research and practice. Prentice-Hall, Englewood Cliffs (1990)

Vygotsky, L.: Mind in society: The development of higher psychological processes. Cole, M., John-Steiner, V., Scribner, S., Souberman, E. (eds.) Harvard University, Cambridge (1978)

Webster, J., Hackley, P.: Teaching effectiveness in technology-mediated distance learning. Academy of Management Journal 40(6), 128 (1997)

Weiner, J.: Asymmetric competition in plant populations. Trends in Ecology and Evolution 5, 360-364 (1990)

Young, M.: The motivational effects of the classroom environment in facilitating self-regulated learning. Journal of Marketing Education 27(1), 25-40 (2005)

Young, M., Klemz, B., Murphy, J.: Enhancing learning outcomes: The effects of instructional technology, learning styles, instructional methods, and student behaviour. Journal of Marketing Education 25(2), 130-142 (2003) 